TITLE:

\title{
A NEW SPECIES OF THE \\ INTERSTITIAL EOLIDACEAN GENUS PSEUDOVERMIS (OPISTHOBRANCHIA) FROM KII, MIDDLE JAPAN
}

\section{AUTHOR(S):}

Hamatani, Iwao; Nunomura, Noboru

\section{CITATION:}

Hamatani, Iwao ...[et al]. A NEW SPECIES OF THE INTERSTITIAL EOLIDACEAN GENUS

PSEUDOVERMIS (OPISTHOBRANCHIA) FROM KII, MIDDLE JAPAN. PUBLICATIONS OF THE SETO MARINE BIOLOGICAL LABORATORY 1973, 21(2): 67-71

ISSUE DATE:

1973-03-31

URL:

http://hdl.handle.net/2433/175811

RIGHT: 


\title{
A NEW SPECIES OF THE INTERSTITIAL EOLIDACEAN GENUS PSEUDO VERMIS (OPISTHOBRANCHIA) FROM KII, MIDDLE JAPAN ${ }^{1)}$
}

\author{
IWAO HAMATANI \\ Biological Laboratory, Tennoji Senior High School of the \\ Osaka Kyoiku University, Osaka \\ and \\ NOBORU NUNOMURA \\ Seto Marine Biological Laboratory, Sirahama
}

With Text-figures $1-2$

Hitherto, none has been reported on any interstitial opisthobranch in Japan. On September 2, 1971, while the junior author was observing interstitial animals in the sandy intertidal zone near the Seto Marine Biological Laboratory, he happened to find a specimen of pecular vermiform animal, together with some archiannelids, nemertineans and some turbellarians. Later he obtained several more specimens of the same animal from nearly the same habitat. At the suggestion by Dr. S. Nishimura of the Seto Marine Biological Laboratory who thought that it might be an interstitial opisthobranch of the genus Pseudovermis, the junior author had a contact with the senior author for more detailed morphological observation and more precise identification. As the result of each other's observation and discussion, both authors have agreed that the present form represents a new species belonging to the above-mentioned genus.

More resently, on August 12, 1972, the junior author collected an additional specimen at the same habitat, which was examined through joint work for external morphology in living state and then cut into a series of transverse sections, $10 \mu$ in thickness, for the study of internal organs which would be reported on in future. Description of jaw and radula were made on two specimens previously collected and preserved in alcohol.

Before going further, both authors wish to thank Dr. K. Baba for his kind suggestions and Dr. T. Tokioka of the Seto Marine Biological Laboratory for reading the manuscript. The junior author wishes to express his hearty thanks to Dr. S. Nishimura for his advices. The senior author wishes to express his hearty thanks to Dr. A. G.

1) Contributions from the Seto Marine Biological Laboratory, No. 576.

Publ. Seto Mar. Biol. Lab., XXI (2), 67-71, $1973 . \quad$ (Article 6) 

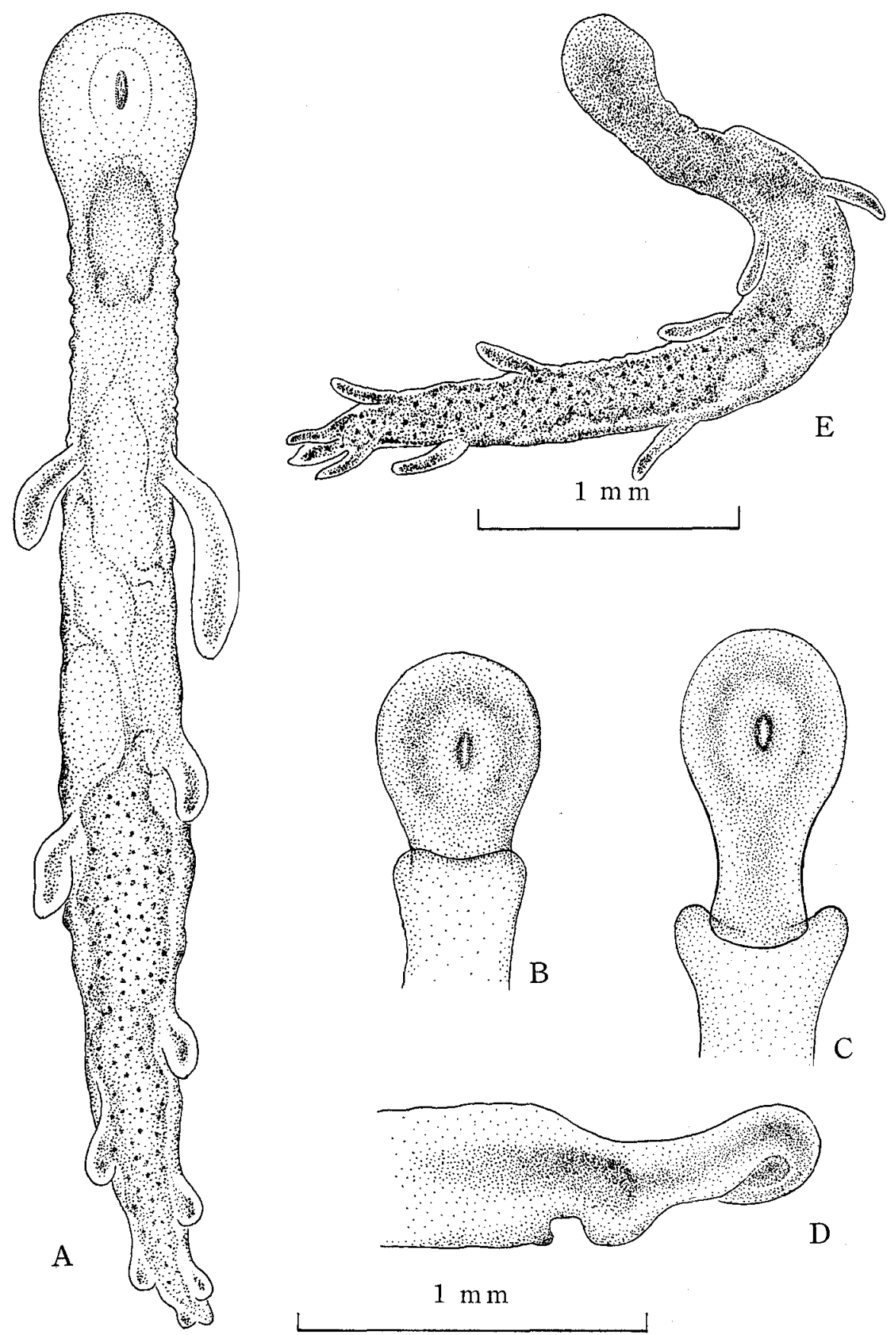

$1 \mathrm{~mm}$

Fig. 1. Pseudovermis japonicus Hamatani and Nunomura, sp. nov.

A-D. The living specimen collected on August 12, 1972.

A. Whole animal, dorsal. B and C. Head, ventral. D. Head, lateral.

E. The living specimen collected on September 7, 1971. Whole animal, dorsal, drawn from microphotographs, taken by Nunomura, of the living animal. 
Smith of the California Academy of Science for his kindness to supply him with a copy of A. Fize's paper indispensable for the present study.

\section{Superfamily Eueolidoidea \\ Tribe Pleuroprocta \\ Family Pseudovermidae}

Genus Pseudovermis Periaslavzeff, 1891

Pseudovermis japonicus Hamatani \& Nunomura, sp. nov.

(Japanese name: Yamato-Sunaminoumiushi, new name)

Description: The living animal is vermiform (Fig. 1, A, E), about $4 \mathrm{~mm}$ in length and 0.3 to $0.4 \mathrm{~mm}$ in breadth in a fully extended state. It is somewhat translucent and whitish, but with a slight yellowish tint in colour; visceral organs are visible narrowly through the body wall, especially the liver is defined as a yellowish brown mass specled with small light brownish spots. The head is flattened dorsi-ventrally, ovoid in outline and cuticulated in shape. This seems to be an adaptation to an interstitial life in coarse sand as in case of the head-shielded cephalaspid opisthobranchs. The mouth opens at the centre on the ventral surface of the head, as a short longitudinal slit. Both eyes and rhinophores are indiscernible on the head. A series of five cerata are arranged on each dorso-lateral side of the body, the first ones are paired but others are approximately alternate. They are finger-shaped and descreasing in length posteriorly, so that in an examined specimen the last two of each series are reduced into merely button-like protuberances. In another specimen, however, all cerata may be fingershaped as shown in Fig. 1, E. No cnidosac nor cnidocyst has far been found in the ceras in any examied specimen. The body ends in a short tail which is very adhesive for its suctional ability. The foot is rounded. No spicules are found in the epidermis. The lateral mandible (Fig. 2, B) of the buccal bulb have each a row approximately 25 teeth on the anterior border, and at least about half of them are sharply-pointed. The very gently curved inner border of the mandible seen in the transvers section (Fig. 2, C) is characteristic for the present species. Radula formula is $1.1 .1 \times 27-33$. The radula (Fig. 2, A) is sharply bent between the 6 th and 7 th teeth in the lower part of the series. The broad median plate (Fig. 2, D) is provided with a strong median tooth and four or five lateral denticles on either side. The median tooth is distinctly taller than the lateral denticles which increase very slightly in size toward the outermost one. The lateral plates are slender and pointed at the tip; they may be simple (Fig. F) or furnished with a secondary sharp denticle (Fig. E) about half as long as the plate. The penis is devoid of the cuticular stylet that is discernible in P. salamandrops (see Marcus, 1953, p115 and pl. 4, fig. 21). The present form is named here, by consensus of both authors, japonicus, since this is the first interstitial opisthobranch of the genus Pseudovermis ever recorded in Japan. 

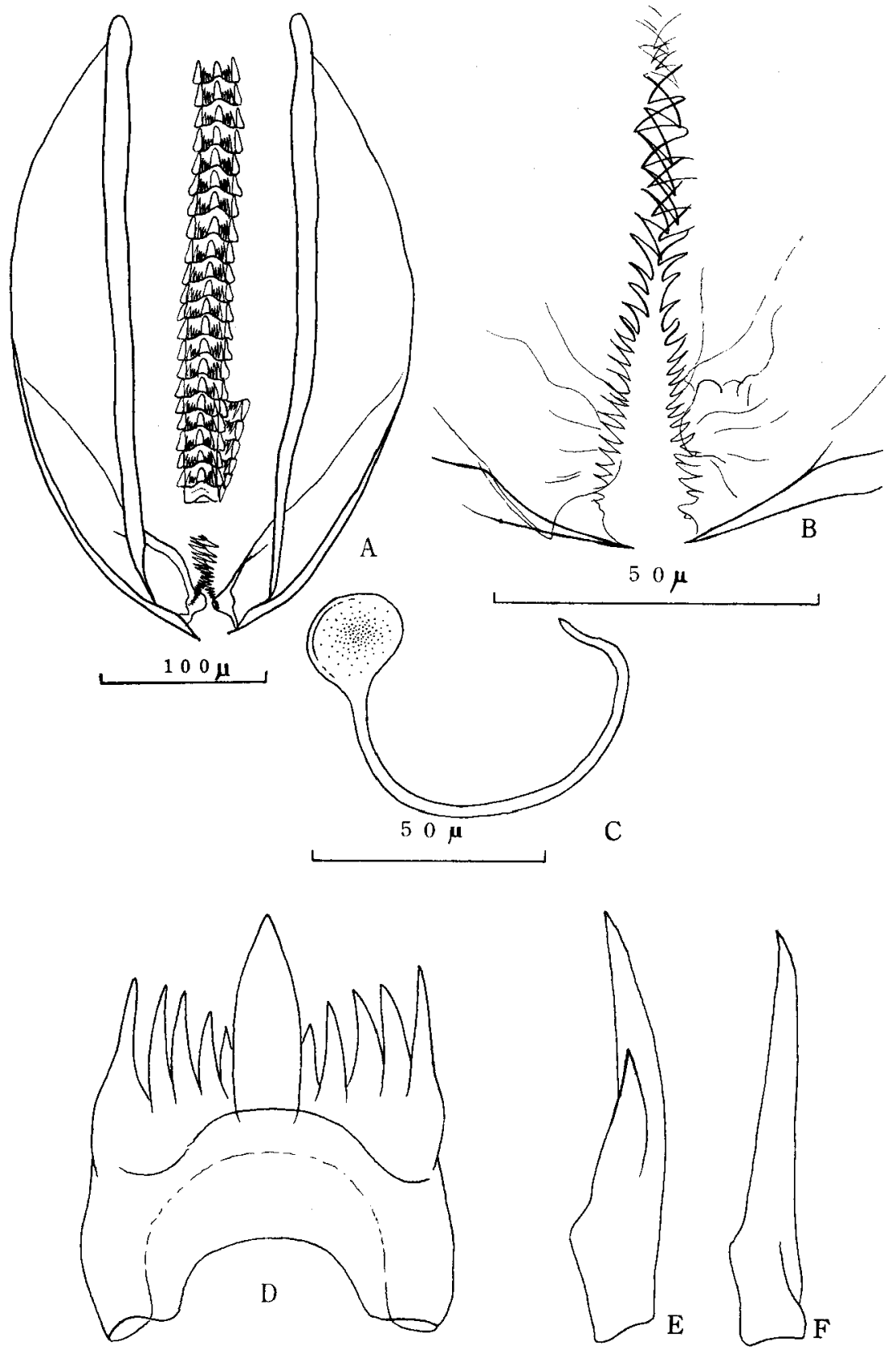

$20 \mu$

Fig. 2. Pseudovermis japonicus Hamatani and Nunomura, sp. nov.

A. Radula and mandible in their original relative situations.

B. Rows of teeth on the anterior border of lateral mandibles.

C. Transvers section of the border of mandible. D. Median tooth plate.

E. Lateral plate furnished with a denticle.

F. Simple lateral plate. 
Remarks: So far as the authors are aware, the following ten species have been recognized as valid in the genus Pseudovermis Periaslavzeff, 1891 from various parts of the world.

1. Pseudovermis paradoxus Kowalevsky, 1891. Black Sea.

2. Pseudovermis papillifer Kowalevsky, 1901. Aegean Sea.

3. Pseudovermis salamandrops Ev. Marcus, 1953. São Sebastião, Brazil.

4. Pseudovermis schulzi Marcus and Marcus, 1955. Arcachon, France.

5. Pseudovermis axi Marcus and Marcus, 1955. Banyulus-sur-Mer, France.

6. Pseudovermis setensis Fize, 1961. Gulf of Lion, France.

7. Pseudovermis kowalevskyi Salvini-Plawen and Sterrer, 1968. Aegean Sea.

8. Pseudovermis boadeni Salvini-Plawen and Sterrer, 1968. Anglesey, England.

9. Pseudovermis mortoni Challis, 1969. Guadalcanal.

10. Pseudovermis hancocki Challis, 1969. New Zealand.

Pseudovermis japonicus sp. nov. is apparently allied most closely to $P$. salamandrops Ev. Marcus, 1953, in some external aspects (lacking eyes, cerata about 5 on each side, etc.) and in the shape of radular teeth. However, the former is distinctly separated from the latter by the following features: (1) the penis without cuticular stylet, (2) more teeth, about two times as many, on the anterior border of the lateral mandible, (3) less difference in length among the denticles of the median plate, and (4) the inner border of the mandible more gently curved in the transvers section.

\section{LITERATURE CITED}

Challis, D. A. 1969. An interstitial fauna transect of a Solomon Islands sandy beach. Phil. Trans. Roy. Soc. B 255, pp. 517-526.

1969. An ecological account of the marine interstitial Opisthobranchs of the British Solomon Islands Protectorate. Phil. Trans. Roy. Soc. B 255, pp. 527-539.

1969. New species of Pseudovermis (Opisthobranchia: Aeolidacea) from New Zealand and the Solomon Islands. Trans. R. Soc. N. Z., Biol. Sciences, vol. 11, no. 10, pp. 153-165.

Fize, A. 1961. Note préliminaire sur Pseudovermis setensis n. sp., Mollusque Opisthobranche Eolidien Mésopsammique de la côte languedocienne. Bull. Soc. Zool. Fr., 86, nos. 2-3, pp. 253-260.

Kowalevsky, A. 1901. Etudes anatomiques sur la genre Pseudovermis. Zap. imp. Akad. Nauk, S. Petersburg, 12 (4)., pp. 1-28. (Quoted through Salvini-Plawen and Sterrer, 1968)

Marcus, Ev. 1953. The Opisthobranch Pseudovermis from Brazil. Bol. Fac. Ciên. Univ. São Paulo, Zool., no. 18, pp. 109-127.

Marcus \& Marcus, 1955. Über Sand-Opisthobranchia. Kieler Meeresf., Bd 11, pp. 230-243.

Salvini-Plawen, L. \& Sterrer, W. 1968. Zur Kenntnis der mesopsammalen Gattung Pseudovermis (Gastropoda, Nudibranchia). Helgoländer Wiss. Meeresunters. Bd. 18, pp. 69-77. 